\section{NEW UNIVERSITY}

\section{Campus in Tropical Australia}

\section{from a Correspondent}

ONE of the events marking the bicentenary of Captain Cook's discovery of eastern Australia is the opening of a university which bears his name. The bill setting up the James Cook University of North Quecnsland received royal assent during the Queen's visit on April 20. The new university was previously the University College of Townsville, part of the University of Queensland, Brisbane, promoted to full status after nine years. Situated on the Coral Sea coast near the Great Barrier Reef, the university at Townsville is the first in tropical Australia. The vice-chancellor is Dr K. J. C. Black, who was appointed warden of the college in 1963.

All facilities aro being transforred from the present two campuses to a 650 acre parkland site in a natural amphitheatre bounded by the Mount Stuart Range. Most of the students, who number more than 1,200, are accommodated in residential colleges in the new setting. This year there are twenty-five per cent more matriculants than last year, a trend which is expected to continue.

This year ordinary and honours bachelors and higher degree courses will be offered in faculties of arts, commerce and cconomics, education, engineering and science. There are also provisions for candidates for other degrees at the University of Queensland, including medicine, dentistry, agriculture, veterinary science and law, to spend their first year at Townsville. A graduate school of tropical veterinary science was founded last year.

The situation of Townsville on the Coral Sea coast near the Great Barrier Reef is ideal for marine scientists. There will be opportunity for collaboration with the Australian Institute of Marine Science, which is to be set up at Townsville. The university is to have its own department of marine sciences, and has been allocated funds for a rescarch vessel.

In the department of chemistry, whore particular emphasis is placed on carbohydrates, research interests include the structure and metabolism of polysaccharides of tropical flora, and aspects of ruminant metabolism, as well as more fundamontal chemical topies. Research intercsts in the department of physics are principally in radiophysics, wave propagation and low energy nuclear physics. The department is also responsiblo for the Tropical Research Unit in Atmosphere and Meteorological Physics.

In the department of engincering and geology, courscs and research are oriented particularly towards industrial and mining developments in Qucensland and other parts of Australia. Close liaison is encouraged with private industry and government agencies, which supply scientists who make specialist contributions to the tcaching of the university.

As its graduate studies extend in scope, the James Cook University will increase its intake of students from South-East Asian, African and other overseas countries, especially in subjects of vital importance to tropical development, for example, veterinary science and engineering. It is one of the aims of this university to make its facilities available to other countries with tropical needs, as well as serving North Queensland and the rest of tropical Australia.

\section{Parliament in Britain}

Military Hovercraft

THE government has no intention of abandoning any projects concerned with military hovercraft development. This assurance was given by Lord DelacourtSmith, Minister of State, Ministry of Technology, in reply to a question from the Earl of Kinnoull. $\mathrm{He}$ said that the BH7 model, which is now undergoing trials, has alrcady been bought by the Ministry of Technology for evaluation by the Navy and that five models of the SRN 6, four of the SRN 5 and one of the SRN 3 are in service. The government is also discussing the possibility of assistance for further development both of existing and of planned craft with the British Hovercraft Corporation. (Oral answers, Lords, April 14.)

\section{CS Gas}

Although Mr Eric Moonman said that the United States produced $1,207,000 \mathrm{lb}$ of CS gas in 1967 , $4,251,000 \mathrm{lb}$ in 1968 , and $6,063,000 \mathrm{lb}$ in 1969 , under licence to the British government, he was told by $\mathrm{Mr}$ Ivor Richard that no money has been received arising from the licensing arrangements. (Written answers, April 16.)

\section{Power Stations}

Mr Atan WtLltams, joint parliamentary secretary, Ministry of Technology, said that on January 1 this year, the Central Electricity Generating Board had 46,035 MW total gencrating capacity. This consisted of $35,957 \mathrm{MW}$ coal fired, 4,766 MW oil fired, and 3,138 MW nuclear, and the rest was made up from coal-gas fired stations and other sources. (Reply to a question from $\mathrm{Mr}$ Eric Ogden, written answers, April 16.)

\section{Aerospace Industry}

THE British aerospace industry was the subject of a wide-ranging debate in the House of Lords last week. Discussion touched upon almost every aspect of the industry, and was libcrally sprinkled with pleas for Britain to become more involved in space research. The Earl of Bessborough, who opened the debate, said, for example, that no country which wishes to remain in the forefront of advanced technology can fail to be involved in space, and if the British government can go in with the United States in the development of the space shuttle, then it ought to do so. But that viewpoint did not entirely carry the day. In characteristic style, Lord Ritchic-Calder declared his opposition to manned spaceflight. He said that he has always deplored the Apollo mission for its waste of human ingenuity.

As far as the British acrospace industry is concerned, Lord Delacourt-Smith said that the size of the industry must reflect the amount of work which it manages to obtain, and that it is not the business of the government to keep it at any particular level. He also said that cven though the future of the industry may seem to lie in international cooperation-especially with European countries-it is not government policy to pursue this courso willy-nilly and rule out national projects automatically. The Minister of State concluded by saying that although the government may play a major part in the British aerospace industry, it is essentially for the industry to carry out its own longterm planning in the light of its own commcrcial judgment. (Debate, Lords, April 15.) 